\title{
Free enterprise in South Africa and academic responsibility
}

\author{
Geert $L$ de Wet \\ Department of Economics, Rand Afrikaans University, Johannesburg
}

\author{
Professorial inaugural lecture, Rand Afrikaans \\ University, September 1978. Originally delivered in Afrikaans
}

\begin{abstract}
Although few people may realize it, the free enterprise system occupies a front line position in the onslaught against South Africa. It is therefore important that we are aware of the advantages as well as the disadvantages of the system in order that we do not cherish expectations which cannot materialize. The free enterprise system achieves the best results, from the point of view of efficiency, but it does have shortcomings as well. The advantages of free enterprise for South Africa must be sought far beyond the traditional arguments and relate, in fact, to a community's view of life itself. The discipline of free enterprise nurtures tolerance towards one's competition and it supplies the people with personal property which they will be prepared to defend. An important characteristic of the system of free enterprise is the fact that it teaches people to outwit their competitors intellectually instead of physical removal. This helps to create a community in which one may live an ordered life in safety.

S. Afr. J. Bus Mgmt 1979, 10: 136-143
\end{abstract}

Alhoewel min mense dit miskien so insien, beklee die stelsel van vrye onderneming 'n sentrale posisie in die aanslag teen Suid-Afrika. Dit is daarom belangrik dat ons bewus is van die voor-sowel as die nadele van die stelsel, sodat ons nie verwagtinge koester wat nie vervul kan word nie. Alhoewel dit wil voorkom of vrye onderneming uit 'n doeltreffendheidsoogpunt die beste resultate lewer, is dit ook aan sekere tekortkominge onderhewig. Die voordele van vrye onderneming in SuidAfrika, moet anderkant die tradisionele argumente gesoek word, aangesien dit 'n gemeenskap se hele lewenstyl raak. Die dissipline van vrye onderneming skep verdraagsaamheid teenoor jou teenstanders en dit verskaf aan mense persoonlike eiendom wat hulle bereid sal wees om te verdedig. ' $n$ Besondere voordeel is die feit dat dit mense leer om hul teenstanders met intellek te uitoorlè, eerder as om hulle fisies uit die weg te ruim. Dit dra by tot die skepping van 'n ordelike en veilige gemeenskap.

S.-Afr. Tydskr. BedryfsI. 1979, 10: 136-143

Geert L. de Wet

Professor, Department of Economics, Rand Afrikaans University, P.O. Box 524, Johannesburg 2000, South Africa
The liberal economic system, better known as the free enterprise system, may be viewed as the economic connoisseur's system. It operates invisibly and demands, therefore, the ability to think in abstract terms in order to perceive the cumulative effect of several diverse forces before one is persuaded about the advantages of the system. When events turn adversely on the economic front, people are often tempted to follow the seemingly obvious and easy road, by attempting to solve the problem through direct measures. I refer to a seemingly obvious road, as these people do not take account of the invisible working of the system of free enterprise which reacts to such direct intervention in a way which often aggravates the original problem, while the solution of the problem remains evasive and new measures are continously needed to cope with new problems that arise along the road. In the end the interventionary measures become so extensive and intricate, that it is difficult to distinguish their essential components.

These considerations moved the Nobel prize laureate and arch liberal, Von Hayek, to warn that too much planning and consequent deviation from free enterprise, in fact points the way to serfdom. ${ }^{1}$ Free enterprise not only promises economic efficiency, but cultivates attitudes which promote a democratic life-style. These aspects will be expanded upon later. In the meantime it must be emphasized that, should it be important that the community be persuaded of the advantages of the system of free enterprise and kept that way, it must be informed and educated, in view of the fact that free enterprise operates in an indirect and sophisticated way so that its advantages are not immediately obvious. The advantages of the system will be reviewed here because, in the light of the external pressure on the country and in view of the almost daily domestic changes being experienced it is important that the people of this country accept the principle of free enterprise for the sake of their own survival. In the same way that a general, approaching a battle ground, considers not only the positive characteristics of his weaponry, but especially also its weaknesses, the proponents of free enterprise must make sure that they take account of the system's weaknesses too. Special emphasis will be placed on this area as this may cast some new light 
to assist in our efforts to preserve our basic freedom within the customary constraints.

\section{The working of free enterprise}

As we all know, the system of free enterprise is based on the principle that each individual person promotes his or her own interest, within certain constraints. These individuals can be classified into two broad groups, namely consumers and producers. Consumers consume final goods and services and supply primary inputs, while the producers combine primary and intermediary inputs in the technical production process in order to produce intermediary and final products. Promoting his own interest implies, in the case of the consumer, that he strives to obtain a set of consumption goods and services and to supply labour at any place and at any point in time, within the constraint of his income, and optimal in terms of his own preferences. (Income should be viewed in a general sense, comprising the consumer's entire stock of wealth.) In other words, should we define a utility function over the preference scale of the consumer, the position would be one where he strives to maximize his utility, within the constraint of his income and given the product prices. ${ }^{2}$ It is possible to determine, from this, that the quantity of each product demanded, at the optimum position, will depend upon the prices of all goods and services that enter his preference pattern, thus affecting his welfare, and his income..$^{3, p p 26-39}$ This fact should be kept in mind. In the case of the producer, promoting his own interest implies that he attempts to maximize profits, defined as the sum of all products sold, each multiplied by its price, while the prices of the products and the production technology are given. From this can be deduced that the quantity of each product to be supplied at the maximum profit level, will depend upon the prices of the products and the prices of the inputs..$^{3 . p p 61-64}$ This fact is important for future argument.

If it is possible to ensure that the price being paid by the consumer and the price being received by the producer is the same, for all products, all consumers and all producers, while each individual producer and each individual consumer accept prices as given, then a certain optimal welfare position will be reached when each producer maximizes profits, given the production possibilities, and each consumer maximizes utility, given his or her income. This result follows from the so-called duality theorem in micro-economics. It is on the one hand possible to determine what a specific social welfare optimum would look like. On the other hand, under the above circumstances, such a social welfare optimum could indeed be reached.

This specific optimal social position, which in economic theory is the ultimate objectively obtainable situation, is the renowned Pareto-equilibrium. It is an equilibrium in which it is impossible to increase the welfare of one person, without decreasing that of another. There are undoubtedly many attainable positions in an economic system. As long as the science of economics wants to maintain objectivity when solving problems, it must seek situations which will be accepted by everybody. The Pareto-equilibrium is the farthest that one may move in that direction. A change which benefits some, without affecting others negatively, must be ac- cepted by all rational beings, while we have no place in an objective science for outright irrationality. Therefore, according to this norm, equilibrium has been reached when it is no longer possible to benefit a person, without decreasing the welfare of another. This equilibrium is, in economic terminology, characterized by equality between the marginal rate of substitution in consumption between any two products for all consumers, while it simultaneously equals the marginal rate of transformation between those same two products in production, the latter being the same for all producers. It is important to note the way in which this optimum situation is attained and in particular the constraints that are applicable. The Pareto-optimum is obtained by maximizing one person's utility, within the constraints that

- the utility of each other person is being left unaltered,

- production is being carried out in the most efficient way, given the technical production boundaries, and

- the total demand for a product, summed over all consumers, equals the total supply of it, summed over all producers.

For this reason it is important to pay attention to the type, as well as to the number of constraints that apply.

A system of perfect competition is characterized by the fact that no producer or consumer can influence the price of a product, so that the set of prices, consisting of one price for each product, can be taken as given by the individual. Implicit in this situation is the fact that the price which the producer receives is the same as the price the consumer pays. When the consumer maximizes his utility, the marginal rate of substitution in consumption between any two products equals the ratio of the prices of the two products, where the marginal rate of substitution is defined as the ratio of the marginal utility of two products.

Because all consumers pay the same price for the same product, it is obvious that the marginal rate of substitution between any two products, in equilibrium, will be equal for all consumers, since each one equates it to the same price ratio. In the same way, the producer maximizes his profit when the marginal rate of transformation in production between any two products equals the price ratio of the two products. These transformation rates will likewise be the same for all producers because they receive the same price for the same product. The fact that pure competition will take the economic system to Pareto-optimality, should be evident by this time: because consumers pay the same prices which are received by producers, the marginal rates of substitution in consumption between pairs of products equal the marginal rates of transformation in production between the same products when supply and demand are in equilibrium. This is exactly the Pareto-optimum where it is impossible to increase the welfare of one person, without decreasing that of another.

The foregoing review of the efficiency of the system of free enterprise, may be rather boring to some economists. It is given, however, in order that the picture may be clear 
when we look at the cornerstones of efficiency in free enterprise, as well as efficiency itself. Although the author is a supporter of free enterprise and regards it as one of the main instruments in defending this country, we should also be perfectly aware of the constraints, shortcomings and qualifications that arise. Because South Africans grow up in a system of relative free enterprise, many people are often inclined to accept the advantages of the system, without ever considering or even knowing the strict restrictions required for the system to be efficient. In this way, one may easily be caught off-guard.

\section{The basic constraints upon the advantages of free enterprise}

The first aspect that must be scrutinized, is the renowned efficiency of free enterprise. Efficiency is an ambiguous concept. When somebody speaks in favour of free enterprise on account of its efficiency, some or other smoothly operating, desirable situation, including a high and fastincreasing standard of living is meant. It creates the impression that whoever lives in this system, will be productive and content. The foregoing analysis, however, showed that efficiency, as being produced by free enterprise, has a specific meaning: given the welfare of all persons but one, free enterprise maximizes the welfare of this last person. It produces a situation in which it is impossible to benefit a person, without harming somebody else. Although this is certainly a plausible and desirable situation, it remains a rather restricted one. Nothing is said about the relative welfare positions of the different individuals, and free enterprise can indeed do nothing about it. Just how restricted the Pareto-optimum is, should be clear when one is reminded that it was Paretooptimal when Nero played the violin, while beholding a burning Rome. It was not possible to increase the welfare of the Romans by extinguishing the fire, without decreasing Nero's welfare. Yet, one still feels that it might have been a good thing to put an end to the fire. ${ }^{4}$

The type of efficiency brought about by free enterprise, is therefore not always or necessarily desirable. In view of this fact, government intervention in the operation of the system is often needed. Once the economic system has forced a Pareto-optimum onto the community, it may be necessary, from a social point of view, to change the relative welfare positions of the different members of the community. In its strict objectivity, free enterprise would not do it and it becomes necessary to bring in a subject with the necessary authority to effect the desired changes. Authority is necessary on account of the fact that those whose welfare has to be decreased, are certainly not going to accept it willingly in a world without such an authority subject. Which norms should be used to accomplish the welfare redistribution, is not relevant in the present context, as we are now only concerned with the first important reason for a government to intervene in the operation of the economic system. It is interesting that even majority decision making will not necessarily extinguish all restraint, not even among the majority. It has been known, for that matter, for quite a long time that majority decision making may lead to socalled intransitive decisions, where $\mathbf{A}$ is preferred to $\mathbf{B}, \mathbf{B}$ to $\mathrm{C}$, but $\mathrm{C}$ to $\mathrm{A}$. The following preference pattern illustrates the possibility:

\begin{tabular}{cccc}
\multicolumn{2}{c}{ Preference pattern } & Majority decision rul \\
1 & 2 & 3 & \\
A & B & C & A preferred to B \\
B & C & A & B preferred to C \\
C & A & B & C preferred to A
\end{tabular}

The possibility that free enterprise may lead the economy to a weak efficiency position cannot be avoided, because it is simply not possible to weigh individual subjects' relative welfare situations up against each other in an objective and therefore acceptable way. After more than half a century's search for ways of aggregating individual to social welfare, Kenneth Arrow showed that in general it is not possible. Economists have tried to construct a socalled social welfare function on the basis of individual welfare functions. Once this has been achieved, it will be possible to weigh the welfare gain of one person against the welfare loss of another, in social terms. In this way it would be possible to redistribute the relative welfare positions in such a way that society gains in a net sense. Arrow's Impossibility Theorem showed, however, that such a social welfare function based on individual preference structures cannot be formulated within certain reasonable constraints. ${ }^{5}$ The constraints are that the choices flowing from the social welfare function should yield a complete, reflexive and transitive ordering of alternatives; the function should be based on any possible logical set of individual preferences; there must be nonnegative association between individual and social orderings; the social ordering should not depend on anything outside the individual orderings; it should not be the ordering of one individual (non-dictatorial); and the ordering should not be imposed on the community from outside. $^{6}$

These constraints try to define a very broadly accepted social welfare function, which adheres to some basic and uncomplicated democratic principles. Arrow showed that such a social welfare function cannot be formulated, with the implication that we have no objective frame of reference according to which welfare redistributions may be done. Whatever a government does, must, therefore, necessarily be rebuked by some, while it has been shown that governments must act from time to time, when social as opposed to individual welfare is at stake.

It is therefore not surprising that, in this country with her relatively free enterprise, relative democracy and relative and increasing presence of majority rule, there is so much difference of opinion!

During the discussion about the operation of free enterprise, it appeared that the quantity of a product demanded by a consumer, is determined by the prices of all goods and services entering his or her welfare function as well as by individual income. It appeared at the same time that the quantity produced by a producer would depend upon the prices of the inputs and outputs in the production process. The optimal working of free enterprise is based on the observation that Pareto-optimality will follow when each individual promotes his own interest, within certain behaviour rules.

Yet, even if we accept this dubious efficiency norm, a host of practical problems still remain. In the first place, the amount of goods and services a consumer can buy is restricted by his income, although it does not affect the 
attainment and character of the equilibrium from the point of view of equality between substitution rates and price ratios. However, when the income of some people is extremely high and that of others very low, it may result in a somewhat unsatisfactory Pareto-equilibrium. This, in fact, is nothing but the old problem of a skew income distribution. Solving this problem immediately creates two new ones: what relative constellation of incomes is the desired one, and how can the existing distribution be changed towards the desired one. Economics cannot provide a satisfactory answer to the first new problem. The aforementioned Arrow Theorem explains why. There simply is not a reasonable and objective economic norm through which one person's welfare loss may be compared with another's gain. This does not mean that there are no norms whatsoever, but they must be sought outside the science of economics. One should take care not to be too dogmatic on these issues, however, because differences of opinion may be expected in South Africa, in view of the rather heterogeneous population composition. The Arrow Theorem also implies that there exists no reasonable hope of eliminating these differences of opinion. Once we have decided, however, what the welfare distribution should look like in the optimal situation, economics could provide us with suggestions about the most efficient way to accomplish the redistribution.

As long as we accept the basic motivation of free enterprise and private initiative, the redistribution should be accomplished through indirect government action. While taxes on the one hand and subsidies on the other may be viewed as indirect interventionary measures, they may prove counterproductive if used indiscreetly and taken too far. We should, in addition to all other measures, also keep the dynamic working of the system in mind. If its dynamic working is not considered adequately, one may end up with a general welfare decrease, instead of a redistribution. Saving is a part of the consumer's expenditure possibilities. When income grows, savings constitute a greater absolute and relative part of total income expenditure. By indiscreetly taxing income away from the higher income group to the lower one, we may decrease expenditure on savings. This would diminish the relative availability of funds for investment purposes, and would thus negatively affect the productive capacity, causing a decline in the availability of goods and services. Those who have looked forward to an increase in their relative income may very soon find themselves in a position where the total supply of goods and services has declined and supply and demand are equalized by increased prices. The intended increase in welfare as measured by increased access to goods and services, may not materialize at all. Particularly in South Africa this possibility is rather strong. The lower income group is so far from expenditure saturation, that little if any of the extra income will be saved. The decline of savings by the higher income group would thus not be neutralized by a similar increase by the lower income group, so that a general welfare decline would eventually set in.

The way to prevent this unfavourable situation from developing, would be to ensure that the necessary goods and services that will increase the lower income group's real welfare, are produced. This may be accomplished by getting hold of the higher income group's savings by way of loans instead of taxes, and by investing these in the human capital of the lower income group, by increasing their level of training. Increasing their level of training would increase their ability to produce, whereby they could supply the goods and services necessary to increase their welfare. At the same time income would be generated from which interest payments and capital repayments on the original loans can be made. We are thus back at a type of Pareto-principle: improve the Pareto-equilibrium by benefiting some, without harming others, namely the high income group. The tax-subsidy way may seem shorter, but will leave the economy lost in the woods. Increased productivity by way of better training is in fact a longer way, but it emphasizes again the need for sophisticated reasoning and patience when solving economic problems.

The system of free enterprise has so far failed miserably in its efforts to achieve efficiency, even in its restricted form as discussed previously, when there are goods and services which affect the welfare functions of individuals and therefore the community welfare function, without their being priced by the system. Under such circumstances, a gap develops between the equilibrium position of individuals and the optimal equilibrium position for the community as a whole. The latter requires equality between consumption substitution rates and production transformation rates, whether prices exist or not, in order to establish Pareto-efficiency. The fact that free enterprise may arrive at this position follows from the fact that consumers equate their consumption substitution rates and producers their production transformation rates to the same set of price ratios, when each group reaches equilibrium. Equality between consumption substitution and production transformation rates come about without consumers and producers attempting to effect it on purpose. It is simply the result of the existence of prices. When prices do not exist for certain products, a short-circuit develops and the equality between consumption substitution and production transformation rates, necessary from a Pareto-optimum view, simply cannot be realized. Once again it is necessary for the government to intervene in the operation of the system in order to improve the position.

The problem of collective goods and services and externalities is well-known among economists, but its full implications are still not always realized. As the capitalistic economic systems grow and put more goods and services at the disposal of the community, the number of negative and positive externalities increases along with the number of collective goods and services. In view of the fact that the particular production system cannot handle these products, it is evident that the government's relative share in production will increase pari passu with the increase in these products. In the light of the way in which efficiency in the economic system is being reached, it is important that every increase in the government's activity and production should not per se be equated to creeping socialism. When such a change is aimed at handling the ever increasing amount of externalities and collective goods, or at the solution of problems in weighing the relative welfare situations, it is actually assisting free enterprise. It would, of course, be necessary to ensure that government activity is of an assisting nature, and to 
keep efficiency within such activity in mind. The present popular exercise to calculate the increasing share of the government in the GDP, is thus rather dangerous. It does nothing more than report the facts while further and deeper analysis is necessary to determine whether this activity has been assisting free enterprise or not.

The qualifications one has to keep in mind when promoting free enterprise, have so far taken us past two great stumbling blocks: the incompleteness of the efficiency target and the role of prices and income in the achievement of this target. However, an even more serious obstacle in the way of free enterprise as a means of steering the community towards efficient welfare organization, has not yet been touched upon. During the discussion of the optimal operation of the free enterprise system, it was pointed out that it is important to note both the nature and the number of the relevant constraints when optimal behavioural rules are deduced. These behavioural rules are the now well-known equality between marginal substitution and transformation rates with respect to all consumers, producers and any pair of products. These rules are obtained by maximizing the welfare of any one person within the constraints that

- the welfare of all other persons is left intact,

- production is carried out in a technically efficient way, and

- total demand for each product equals its total supply.

There exists, therefore, three types of restrictions and these are expressed in terms of original functions in the relevant variables, so that the optimal behavioural rules are expressed in terms of first derivatives. From the second derivatives we then know that we are actually dealing with maxima. ${ }^{3,}$ ch 2,3,4 Yet, these behavioural rules can only be applied with absolute certainty when the practical situation corresponds exactly to the theoretical exercise. In reality, however, a quite different situation is found in practice. Firstly, very few producers operate in a technically efficient way, on account of many reasons which may all be traced to the fact that they do not necessarily strive towards maximum profits. This, in turn, follows from the fact that instead of perfect competition, one finds various degrees of monopolistic conditions throughout the economy, allowing certain degrees of freedom in their profitability targets, so that they need not follow the strictly most efficient production process.' There furthermore exists in South Africa, as in any other country, a host of rules and regulations applicable to domestic as well as foreign trade, which constitute further constraints within which Pareto-optimality must be sought. These constraints are supplemented by the actions of existing big monopolistic groups, such as sole producers, trade unions, consumer groups and cooperations.

The problem to deduce behavioural rules for the Pareto-optimal situation, now becomes much more complicated. Since there is no possibility of removing these additional restrictions, because they are already institutionalized into the system, they must be accounted for when deducing optimal behavioural rules. It is, however, impossible to determine in general what these new behavioural rules will look like, because the nature and number of additional constraints are uncertain and not universal. It is clear, however, that the new rules will differ from the equality between marginal substitution and transformation rates, and it is consequently not known whether free enterprise will get the system at Paretooptimality or not.

What is more, some of the additional restrictions involve the behaviour of monopolists, which will be expressed in terms of first order derivatives of the original functions, like marginal productivity being some or other function of the price. If we determine the optimal situation in normal fashion, the new behavioural equations will be expressed in terms of second derivatives of the original functions. To determine whether the equilibrium position is actually a maximum, minimum or maybe a saddlepoint, demands knowledge of the third derivatives of the functions. In general, however, economists have no idea what the typical third derivatives of production and welfare functions look like. In short, in view of the existence of additional constraints on our welfare maximization effort, we do not know what the behavioural rules should look like at the Pareto-optimal or efficient point. ${ }^{6, \text { ch } 8: 8}$

This theory about the non-existence or at least the nonidentifiability of a second best situation in the determination of optimal economic welfare situations, has in fact devastating consequences for our normal perception of the advantages of free enterprise. It is important that we keep this in mind when we try to extend decentralized decision making by analogy of the economic experience, to the general social scene. As long as there are additional constraints present somewhere in the system, like nondecentralized decision making in the form of oligopolies or monopolies, we have no guarantee that the introduction of decentralized decision making at other places will increase efficiency. On the contrary, in view of the foregoing arguments, it may even lead to a reduction of efficiency and welfare. We are, in fact, confronted with an all or nothing situation. Decentralized decision making and increased competition can only be guaranteed of success, when applied without exception throughout the economy. Should concentration of power and consequent centralized decision-making be found at some places in the system, the implication of the Theory about the non-existence of a Second Best Situation, is that efficiency and welfare may just as well be increased by promoting centralized decision-making, unless it can be terminated throughout the system at the same time.

These facts cast new light on the role of the government, on the extent of its activities and in particular on our policy with regard to monopoly and competition. Although it is generally accepted that complete perfect competition does not exist, there exists at the same time a belief that more competition is better than less, even if we cannot achieve all-round pefect competition. The concept of effective competition has, consequently, originated and monopolistic conditions are treated in this spirit." From the foregoing arguments it would, however, be just as logical to promote the establishment of economic concentrations, when necessary. This links up with Galbraith's Theory of Countervailing Power. ${ }^{10}$ 
Of course, it is not to say that centralized decision making should now be promoted without exception. The argument only implies that both options should be left open and investigated. In some cases more competition and in other cases less would be the answer. There is, however, a definite shift in emphasis away from the present policy. At present the formation of monopoly power is resisted, unless it appears to be in the public interest that it exists. The Theory about the non-existence of a Second Best implies that it may in cases be actively promoted in areas where it has not yet been found and that anti-monopoly measures should be formulated with even greater care. This argument may sound beneficial. The difficulty lies in the fact that Lypsey and Lancaster's theory is not generally known, as it is found in the area of mathematical economics. It furthermore creates such an uncomfortable position for vested opinion and interests, that many economists rather keep silent about it. The sophisticated nature of modern economics and the need for proper training once again appear clearly.

The factors causing problems for the operation of a free enterprise economic system, are still not depleted. Other factors include indivisibilities, increasing returns to scale, deficient information and transaction costs, ${ }^{6, p 83}$ The main problems and in fact those that are usually overlooked, have been dealt with. The question to be answered now, is why we would still support and promote free enterprise.

\section{The advantages of free enterprise}

In establishing the role of free enterprise in a changing South Africa, it is clear that one should search beyond the traditional arguments, since these may land us in grave difficulties. Yet, emphasis must still be placed upon the fact that problems involved with capitalism's efficiency norm can be overcome. It has been dealt with earlier and it should be remembered that, in case we want to do something about it, we automatically define a specific, active and increasing role for the government in the economic process. The same is true for the solution of the problems of an unequal income distribution, externalities and collective goods. It is not possible to enjoy the advantages of free enterprise and minimize the role of the government. The more advanced a capitalistic system, the bigger the role of government in order to sustain free enterprise.

The problems resulting from the Theory about No Second Best, are indeed serious. Yet all is not lost. The theory implies that we do not know where we find ourselves with respect to efficiency, but it has at the same time also not yet been proved that free enterprise leads to less efficiency. Promoting competition may, in the light of other constraints, lead sometimes to welfare losses, but it may still improve it. It must furthermore be remembered that we are dealing with an increase in decentralized decision making. The essence of free enterprise is not touched by the possibility that increased power concentrations may still be advantageous for social efficiency. Even under such circumstances, competion, private property and the promotion of own interest still remain. Competition, however, is now between a few giants instead of between numerous small enterprises. The argument behind the reasoning of No Second Best, is in fact directed at the indiscreet destruction of some power concentrations, while others remain. Even so, the sum total of all the reservations about free enterprise is such that we need to look at arguments other than economic efficiency in order to strengthen our belief in the system once again. Fortunately, such arguments may be found and they seem to be rather impressive.

The first argument is of a negative nature. The question is what the alternatives are. What can be put in the place of free enterprise? Broadly considered there are two possible substitutes, namely a system based upon tradition and one based upon socialism. The traditional system as found in the underdeveloped world, however, is totally incapable of supporting a modern industrial economy. In the case of socialism, the question is whether that system is free from the problems discussed earlier in connection with free enterprise and the answer is negative. In a system of central planning, many more interpersonal welfare comparisons have to be made. Externalities and collective goods and services, which are not dependent upon the nature of the economic system, are found in a socialistic state as well, and must be coped with. The central planners would equally not be in a position to identify the socially optimal position, as they face the same problem of aggregating from individual to social welfare, and experience diverse constraints on economic activity. Additional problems, revolving around the inflexibility of the bureaucratic machine and the absence of motivation originating from profit maximization also arise.

Given the practical difficulties involved in the operation of free enterprise, its main advantage lies not so much in efficient production, as in the fact that it fits into our general religious and democratic life style. The principle of striving to increase one's own welfare position, within the constraints which the economy imposes on one and within the framework of competition from others, as reflected in price movements, cultivates a specific discipline. This discipline teaches that advantage over one's adversary may be gained by outwitting him but not by removing him physically. The rules of the game are such, that people develop an ability to think faster than others, because this is exactly what free enterprise is all about. One who has a basic belief in an economic system of free enterprise, learns to respect other people's right of possession and their right to promote their own values. This is the direct result of the fact that property rights and the right to make agreements are cornerstones of free enterprise.

People who honour these principles on economic grounds tend to extend this attitude to their everyday life. The fundamental motivation is found in the fact that the free enterprise system, that is capitalism, teaches a person that his own rights to property and to agreement are guaranteed only as long as he allows the same rights and privileges to others. In this way, free enterprise creates a general climate which promotes a stable community free of violence. A system in which all individuals accept this discipline as their life philosophy, would certainly offer a safe and pleasant community in which to live.

Free enterprise based upon private property and private initiative also promotes economic growth. This follows from the fact that an increase in a person's assets 
is not in vain, but increases his welfare permanently as it remains in his possession as long as he desires it to be the case. A basic motivation to explore new routes is therefore cultivated and it is in fact the absence of this motivation which has caused immense troubles for the socialistic countries. Under present circumstances, South Africa can never experience too much growth, and this alone may therefore be a sufficient reason to promote free enterprise.

There thus exists ample reason why a system of free enterprise will be propagated in South Africa. It is, however, also essential to critically analyze some of these deep-rooted beliefs, if only because it is necessary to be aware of both the strong and the weak points of a system. This is the case however strongly one may believe in a system, and it is even more important at the present time when one may be confronted by proponents of other systems.

\section{Academic responsibility}

The academician has an important task in promoting free enterprise in South Africa. It is clear that the free enterprise system is rather sophisticated in its operation and that one has to believe that it will work. Certain falacies about the operation of the system have also been pointed out. The very important Lypsey-Lancaster Theory of (No) Second Best, tends to be ignored by many economists. These matters can only be corrected by sustained training of an ever increasing quality.

As every generation seeks to improve upon the achievements of the past, the new generation of lecturers must increase the standard of economic training; as should in fact also be the case with the generation following the present new one. When one speaks about an increase in the standard of training, it may be viewed as, and may in the end remain, just empty words. An increase in the standard of training is, however, of great importance in the light of the threats to our economic system. It is important that every student of economics knows not only the detail, but also the wider perspective of his subject. In this way the advantages of the system will become clearly evident, and the community will also be able to cope adequately with all arguments for or against the system. It is necessary however, to be more specific with regard to an increase in the standard of living.

Firstly, it is necessary that a great deal more theoretical refinement should enter our economic training. The general position regarding free enterprise, as has been discussed, serves as an example. Misunderstandings among proponents as well as opponents of the system may be cleared up by deeper theoretical insight. There are a few other areas where this necessity is also prominent. Grave misunderstanding continues to exist about the microfoundations of macro-economics, because the true meaning of necessary and sufficient conditions are not grasped and because the implications of non-competitive conditions are still not fully understood. In the area of monetary theory, great debates continue about the necessity of goverment intervention, as if no monetarist had ever heard of externalities and collective products that evade the market in principle. We all make misjudge- true interrelationships among all the various economic variables. During the past recession, one was once again struck by the way in which people are inclined to project the present, without gripping the interrelationships that will bring about a change in present conditions.

Renewed and sharpened theoretical training will certainly contribute towards bridging these gaps in our economic insight. This does not imply that training in the practical application of theory should not receive attention. Research into practical matters remains indispensable for a teacher of economics. Yet, a university remains the proper place for theoretical training at underas well as postgraduate level. A few weeks' practical experience usually brings a student well into the reality of the world around him. At no other place than at University, however, will he get the opportunity to learn his theory properly. He must be taught in such a way that he looks beyond the goals of the firm and the consumer, towards the implications of the operation of our economic system for our material and spiritual well-being over the short and long term.

A proper theoretical training in the modern explanation of the operation of the economic system demands certain preconditions regarding the language and framework within which the subject must be studied. The proofs of most of the theorems that were used in the foregoing discussion are only open to the economist trained in mathematical economics. This is, in fact, the case with the entire modern theory. The big gap that exists between practical economics and the theory may to a great extent be attributed to the fact that the important theoretical development with all its finer detail has occurred in mathematical economics.

Another example may be illuminating. When the question is asked in modern micro-economics, whether the optimal system of perfect competition has an equilibrium, a rather unambiguous positive answer may be given. When it is asked whether this equilibrium is stable, the answer becomes much more uncertain and ambiguous. "Sufficient conditions for stability in certain special, unrealistic cases have been discovered, but no satisfactory general conditions have as yet been found. The most positive aspect in this respect is the fact that nobody has been able to prove the system to be definitely unstable. Micro-economics, which forms the basis of economic science, is therefore not specific on the question whether our economy is inherently stable or not. Could one then be amazed that the world is shaken by business cycles, balance of payments problems, inflation, unemployment and so forth? The solution for these problems must clearly also be searched for at a far deeper level than blaming the government. It may help to reduce frustration when one hits out at the government, but more research has to be done before economists could even understand the problems clearly. Only thereafter may they start to look for solutions. Yet, this area is totally closed for the economist not schooled in mathematics. Of course, mathematics is not important per se, but as a language serving as a vehicle towards understanding the economic system.

Econometrics has a very natural role to play in this attempt towards theoretical refinement, and offer a powerful way of studying those parts of the economy that can 
be analyzed quantitatively. Econometric models help us to determine the consequence of changes in variables or in behavioural equations in such a way that the full interdependence of the economic system may be captured. This interrelationship is, of course, so complicated, that it is impossible for the human brain to handle everything at the same time. Neither in theoretical, nor in practical work can we do without this instrument today. Training, as well as research in this discipline, should therefore receive high priority. During the past eight years or so, definite progress has fortunately been made in the use of econometrics in South Africa. Econometrics was first applied in this country in the construction of the Economic Development plan. Today other government departments as well as the private sector use econometric models as part of their framework for analysis and planning. The task of the university is clearly to provide better training in this respect and to be involved in fundamental econometric research. Yet, notwithstanding its importance in own right, econometrics remain a part of economics and should in future be handled as such.

In the light of the important role that economics has to play in the solution of our structural social problems, especially in view of the contribution that free enterprise has to make, the question arises as to what tangencies exist between economics and the other social sciences. There are indeed many. It demands, however, not only a good knowledge of mathematics and statistics, but also of psychology, sociology, history and other social sciences. The economist can furthermore not afford to live in isolation from the community. He can only fulfil his social obligation if he is able to communicate in simple language with his fellow countrymen. He needs therefore to be able to think sophisticatedly, but to speak plainly. Otherwise the great $f$ ilosophies of his subject will remain closed to all but his colleagues. In fact, the academic economist, engaged in high theory, should at times leave his study and play an active role in the general economic and social organization, while doing practical research.

To summarize then, it can be concluded that the system of free enterprise retains its importance in South Africa, despite definite failures. This is so because it promotes the creation of a stable community, free of violence. The correct and successful promotion of this philosophy demands from the academician sophisticated reasoning, but the ability to communicate in simple terms.

\section{References}

1 VON HAYEK, F. Road to Serfdom. 1944. Chicago Univ. Press, Chicago.

2. DEBREU, G. Theory of value. 1973. Cowless Foundation, Monogr. 17, Yale Univ. Press, New Haven, p.65.

3 MalinVAUD, E. Lectures on micro-economics. North Holland, Amsterdam, 26- 39.

4. SEN, A.K. Collective choice and social welfare. 1970. HoldenDay, London, p.99.

5. ARROW, K.J. A difficulty in the concept of social welfare. $J$. Polit. Econ., 1950 reprinted in MANSFIELD, E., Microeconomics Selected Readings, Norton, New York, 1971, pp $434-450$.

6. DE WET, G.L. 'n Evaluering van die stand van kostevoordeelontleding in die ekonomiese teorie, Unpublished D.Phil Thesis, University of Pretoria, Pretoria, RSA, 1974. Ch. 17.

7. MACHLUP, F. Theories of the firm, marginalist, behavioural, managerial. 1967. Am. Econ. Rev., reprinted in MANSFIELD, E., Op. Cit., pp 99-114.

8. LIPSEY, R.G. \& LANCASTER, K. The general theory of second best. 1956/57. Rev. Econ. Studies. 24(63): 11-32.

9 Report of the Commission of Inquiry into the Regulation of Monopolistic Conditions, Act, 1955, 1977. Government Printer. Pretoria, RSA, pp.93-95.

10. GALBRAITH, J.K. American capitalism: The concept of countervailing power. 1964. Hamilton: London.

11. DEBREU, G. Theory of value. 1954. Wiley \& Sons: New York. pp. $83-93$ and

ARROW, K.J. \& HAHN, F.H. General competitive analysis. 1971. Holden Day: San Fransisco, Ch. 13. 